\title{
ISLAM SEBAGAI "POST-KRISTEN"; DESKRIPSI PERJUMPAAAN TEOLOGIS ISLAM-KRISTEN
}

\section{ISLAM AS "POST-CHRISTIAN"; DESCRIPTION OF THE ISLAMIC- CHRISTIAN THEOLOGICAL ENCOUNTER}

\author{
Samsi Pomalingo ${ }^{1}$ \\ Arfan Nusi ${ }^{2}$ \\ ${ }^{1}$ Universitas Nahdlatul Ulama Gorontalo, Indonesia, samsi.pomalingo@gmail.com \\ ${ }^{2}$ Institut Agama Islam Negeri Sultan Amai Gorontalo, Indonesia, arfan_nusi@yahoo.com
}

\begin{abstract}
This article uses an esoteric approach in explaining the intersection of religions in the Yudaeo tradition. There is a misunderstanding of religion because it is seen from an exoteric approach. As a result, people tend to judge that this religion is right and another is wrong. Whereas Abraham is known as the father of monotheistic religions, namely Judaism, Christianity and Islam. The vision of the JudaeoChristian-Islamic tradition is an indicator of the three religions as monotheistic religions whose teachings are inseparable and cannot be polarized between one another. However, for certain circles, Islam and Christianity are not seen as Yudaeo traditions, because they see the root of the problem that often causes conflicts between Islam and Christianity, especially in the position or capacity of the Koran as Muhaimin. The conflicts that often occur between the two religions often cause discomfort in theological encounters. This resulted in the relationship between the two religions experiencing unfounded "theological" tensions. Even though it is seen in the Yudaeo tradition of Islam-Christianity as a mission religion that descends from God Almighty. where both religions have theological continuity from the aspects of Divinity, Prophethood (prophecy), and revelation. This tradition should be built on the awareness of religiosity between the two adherents of religion (Islam-Christian) who have the same theological roots.
\end{abstract}

\section{Keywords: Religion, Esoteric, Monotheistic}

\begin{abstract}
Abstrak: Artikel ini menggunakan pendekatan esoterik dalam menjelaskan titik temu agama dalam tradisi Yudaeo. Sebab ada kekeliruan pemahaman tentang agama karena dilihat dari pendekatan eksoterik. Akibatnya orang cenderung menghakimi bahwa agama ini benar dan lain salah. Padahal Ibrahim atau Abraham dikenal sebagai Bapa agama moneteistik, yaitu Yahudi, Kristen dan Islam. Visi tradisi Yudaeo-Kristen-Islam menjadi indikator ketiga agama tersebut sebagai agama monoteistik yang ajarannya tak terpisahkan dan tidak bisa dipolarisasi antara satu sama lain. Namun bagi kalangan tertentu, Islam dan Kristen tidak dilihat sebagai tradisi Yudaeo, karena melihat akar masalah yang sering menjadikan konflik antara Islam dan Kristen, terutama pada posisi atau kapasitas al-Qur'an sebagai muhaimin. Konflik yang sering terjadi diantara kedua agama tersebut seringkali melahrikan ketidaknyamanan dalam perjumpaan teologis. Hal ini berakibat pada hubungan kedua agama mengalami ketegangan "teologis" yang tidak mendasar. Padahal dilihat dalam tradisi Yudaeo Islam-Kristen sebagai agama misi yang turun dari Tuhan Yang Maha Esa. dimana kedua agama memiliki keberlaanjutan teologis dari aspek Ketuhanan, Kenabian (nubuat), dan kewahyuan. Tradisi ini harusnya terbangun di atas kesadaran religiusitas diantara kedua penganut agama (Islam-Kristen) yang memiliki akar teologi yang sama.
\end{abstract}

Kata Kunci: Agama, Esoterik, Monoteistik 


\section{FA R A B I}

ISSN $1907-0993$

E ISSN $2442-8264$

Volume 17 Nomor 2 (Desember) 2020

\section{PENDAHULUAN}

Hubungan Islam dan Kristen sampai saat ini diklaim sebagai dua agama yang tidak henti-hentinya terlibat dalam konflik teologis. Keduanya saling mengklaim agama yang paling benar dan lurus. Sehingga perdebatan ini tidak hanya menimbulkan konflik teologis namun juga konflik yang bersifat politik. Sebagai agama misi, keduanya saling terlibat dalam "perebutan" umat (jama'ah). Tidak heran konflik bisa meletus di manamana baik dalam bentuk pembakaran rumah ibadah maupun bom bunuh diri. Padahal agama merupakan kumpulan keyakinan transendental bersama yang telah diturunkan dari orang-orang yang percaya pada Tuhannya. Tuhanlah yang menurunkan agamaagama kepada setiap Nabi-Nya untuk disebarkan kepada umatnya.

Agama yang diturunkan oleh Tuhan sangat beragam diantanya agama Islam dan Kristen. Kedua agama ini tidak hanya mengajarkan penganutnya untuk tidak hanya percaya kepada Tuhan tapi juga mengajarkan nilai-nilai sosial yang menganjurkan penganutnya untuk saling menghargai satu sama lain sebagai makhluk ciptaan Tuhan Yang Maha Esa. Dalam pandangan Schumann, keduanya saling mengkritik satu sama lain. Misalnya al-Qur'an banyak melakukan kritik terhadap praktek dan doktrin yang berkembang pada agama Kristen. ${ }^{1}$

Kritik al-Qur'an terhadap agama-agama sebelumnya, disebabkan karena penganut agama sebelum Islam telah melakukan tahrif atau corruption ${ }^{2}$ (QS. 4:46, 5:13; 5.41, 2:75). Bermula dari praktek tersebut, ajaran-ajaran agama yang dibawa oleh para nabi yang asalnya benar, kemudian disimpangkan. Hal ini terjadi, karena, (ini tentu saja menurut versi Islam) tidak sebagaimana al-Qur'an, pesan-pesan 'Isa misalnya yang berupa wahyu tidak ditulis secara langsung. Injil Markus yang dianggap paling tua, baru ditulis setelah lebih dari 40 tahun dari 'Isa meninggal. Dan umat Kristen, menurut alA'zami $^{3}$ memerlukan kurang lebih 300 tahun untuk mengakui 4 Injil yang dianggap suci, yaitu setelah konsili ${ }^{4}$ Nicea pada tahun $325 \mathrm{M}$.

${ }^{1}$ O. Schumann, Pemikiran Keagamaan dalam Tantangan, (Jakarta: Gramedia, 1993), 191.

${ }^{2}$ Departemen Agama RI, Al-Qur'an al-Karim dan Terjemahnya, (Solo: Qomary, 2006).

${ }^{3}$ Mohammad Mustafa al-Azamai, 'I'Jaz dalam Pemeliharaan Sunnah Nabi Muhammad Saw' dalam Iwan Kusuma Hamdan dkk (penterjemah dan Editor), Mukjizat Al-qur'an dan As-Sunnah tentang IPTEK I. Jakarta: (Gema Insani Press, 1997), 56.

${ }^{4}$ Awaryono, Abdul Ghafur, Kristologi Islam, (Yogyakarta: Pustaka Pelajar, 2006), 96-101. 


\section{F A R A B I}

ISSN $1907-0993$

E ISSN $2442-8264$

Volume 17 Nomor 2 (Desember) 2020

Sampai saat ini orang-orang sering melihat dan memperlebar perbedaan dalam agama-agama. Cara pandang eksklusif dan klaim kebearan (truth claim) merupakan 'perennial problem'dalam sejarah panjang keberagamaan manusia. sehingga sebagian orang mengatakan tidak perlu beragama atau menganut agama-agama tertentu karena agama justru menjadi media pemecah belah yang mengancam eksistensi dan martabat manusia. ${ }^{5}$

Tulisan ini sebenarnya berangkat dari kegelisahan-kegelisahan yang sifatnya teologis terhadap dua agama besar yakni Islam dan Kristen. Disisi lain, banyak tulisantulisan yang cenderung mengurai konflik kedua agama itu. Sehingga muncul berbagai pertanyaan tentang apakah Islam sebagai agama yang menghapus atau menggantikan kedua agama monoteistik sebelumnya (Yahudi-Kristen)? Ataukah agama Islam dipandang sebagai agama yang secara totalitas (blue print) mengungguli kebenaran agama-agama sebelumnya? Lantas, bagaimana dengan keberadaan agama-agama sebelumnya setelah datangnya Islam?

Pertanyaan-pertanyaan tersebut terus saja mengusik. Namun tulisan ini sama sekali tidak ingin menyudutkan atau mengunggulkan suatu agama tertentu, melainkan ingin melihat adakah kontinuitas antara kedua agama semitik tersebut ataukah tidak sama sekali. Permasalahan pokok dalam tulisan ini adalah apa artinya kalau kita mengatakan bahwa Islam sebagai agama post-Kristen? Apakah kita harus mengartikan bahwa post-Kristen sebagai anti-Kristus? Atau bolehkah kita mengatakan bahwa sifat "Post-Kristen" itu berarti bahwa Islam diresapi oleh kebenaran yang termaktub dalam Perjanjian Lama dan Perjanjian Baru dan dalam agama Kristen? Dengan kata lain adakah kesinambungan antara Islam dan agama Kristen?

Untuk menjelaskan pokok permasalahan di atas, maka kita akan menemukan dua teolog dari agama Kristen dengan pandangan yang berbeda, di satu sisi teolog yang menonjolkan adanya kontinuitas antara agama Islam dan Kristen, dan di sisi lain ada pula teolog yang justru menolak kontinuitas antara keduanya.

\section{TEOLOG YANG MENONJOLKAN KONTINUITAS}

Dalam dunia Kristen abad 20 ada pandangan yang mengatakan bahwa adanya kesinambungan antara agama Islam dan Kristen. Penulis akan menjelaskan argumen-

\footnotetext{
${ }^{5}$ Karen Armstrong, Perang Suci (penterjemah) Hikmat Darmawan, (Jakarta: Serambi, 2004), 10.
} 


\section{F A R A B I}

ISSN $1907-0993$

E ISSN $2442-8264$

Volume 17 Nomor 2 (Desember) 2020

argumen para teolog yang melihat adanya kontinuitas antara keduanya dalam beberapa pokok seperti sebab-sebab lahirnya agama Islam, penyembahan terhadap Tuhan (Allah) yang sama, dan adanya akar teologis yang sama antara Islam dan Kristen (termasuk Yahudi) yaitu ibadah Abraham.

\section{Islam lahir sebagai agama tersendiri}

Cregg sebagai seorang penulis terkenal yang telah banyak menulis hubungan antar agama Islam dan Kristen, dalam tulisannya mengatakan bahwa:

Faktor-faktor penunjang naiknya Islam antara lain adalah gagalnya Gereja dalam membawakan jiwa agama Kristen. Kegagalan itu berupa kegagalan dalam kasih sayang, kesucian, dan dalam semangat yang menyala-nyala, satu kegagalan dari roh. Islam berkembang dalam lingkungan agama Kristen yang tidak sempurna. Naiknya agama Islam adalah terjadinya penyebaran baru, yang menyatakan akan menggantikan apa yang tidak pernah diketahuinya dengan tepat. ${ }^{6}$

Pandangan Cregg di atas sangat yakin bahwa seandainya Nabi Muhammad sempat mengenal agama Kristen dengan murni maka mungkin Ia (Muhammad) akan menilai agama Kristen dengan cara yang lain dan tidak akan menempuh jalan lain yang menuju pada lahirnya suatu agama baru. Jadi Islam dalam pandangan Cregg sebenarnya agama yang lahir sendiri namun memiliki hubungan yang baik sebagai pelanjut nilainilai kasih sayang dan semangat kebersamaan dalam keberimanan. Artinya Islam sebenarnya sebagai kelanjutan dari tradisi agama Kristen yang memiliki akar teologis yang sama.

\section{Allah SWT dan Bapa Yesus Kristus}

Banyak dari kalangan teolog Kristen yang berbicara bahwa kepercayaan dan penyembahan kepada Allah dalam agama Islam dan Kristen adalah satu Tuhan yang sama. Pandangan ini tidak dapat diterima oleh mereka yang menolak Islam sebagai agama baru. Namun, mereka tidak sampai berani untuk mengatakan bahwa Islam bukanlah agama yang sejati. Misalnya Zwemer seorang tokoh pengkabaran Injil yang ada di tengah-tengah orang Islam di Jazirah Arab dan di Mesir (1867-1952). Zwemer tidak segan-segan mengatakan bahwa Islam sebagai hasil pekerjaan anti-Kristus. ${ }^{7}$

\footnotetext{
${ }^{6}$ Th. van den End dan Christiaan de Jonge, Sejarah Perjumpaan Gereja dan Islam, (STT Jakarta, 1997), 161.

${ }^{7}$ Ibid.
} 


\section{F A R A B I}

ISSN $1907-0993$

E ISSN $2442-8264$

Volume 17 Nomor 2 (Desember) 2020

Sebenarnya Zwemer hanya menekankan pada perbedaan antara Allah yang disembah dan dikenal. Dalam tradisi Islam, shalat 5 (lima) waktu dihadapan Allah tetapi tidak mengenal Dia. Dalam agama Kristen hal ini tidak mungkin kecuali melalui Yesus Kristus (Yohanes, 14:6). Wawasan Zwemer ini sebetulnya hanya membedakan antara penyembahan terhadap Allah dan pengetahuan akan Dia. Di mana orang-orang Kristen dan Islam mempunyai satu Tuhan tetapi berbeda dalam ide-ide tentang Dia. Cragg dalam bukunya yang terkenal "The Call of the Minaret", mengingatkan kepada orangorang Kristen yang berbahasa Inggris agar mereka jangan mau mempertahankan sebutan "God" dalam bahasa Inggris bila berbicara mengenai Allah. Sebab dengan demikian secara implisit mereka akan menyangkal bahwa "Allah" sama dengan "God". 8 Akhirnya Konsili Vatikan II (1962-1965) juga mengakui bahwa umat Islam menyembah Allah yang Esa, Allah yang sejati, seperti yang tertulis dalam Nostra Aetate bahwa:

"Gereja memandang kepada orang-orang Islam dengan rasa hormat. Mereka menyembah satu Allah, yang hidup dan yang kekal, rahmani dan Maha Kuasa, yang menciptakan langit dan bumi dan yang berbicara kepada manusia. Mereka berusaha takluk dengan segenap hati pada keputusan-keputusan-Nya yang tak terpahamkan". 9

Keputusan Konsili Vatikan II di atas ini mempertegas bahwa Islam dan Kristen memiliki akar teologis yang sama dalam hal keyakinan akan keesaan Tuhan. Sikap menghormati oleh Gereja kepada Islam menunjukan sikap keterbukaan agama Kristen terhadap agama Islam. Keputusan ini harus dihormati sebagai bentuk legitimasi teologis terhadap kontinuitas agama Islam atas agama Islam. Sebab argumentasi yang dibangun dengan keluarnya putusan Konsili Vatikan II itu jika dilihat dari pendekatan esoterik, menunjukan bahwa Islam sebagai Post-Kristen dan bukan anti Kristus.

\section{Islam sebagai Warisan Abraham: Penilaian Massignon terhadap Islam}

Salah seorang teolog Katolik terkemuka yang banyak menghadiri pertemuan antara Islam dan Kristen yaitu Louis Massignon mempunyai visi yang sangat luas tentang hubungan antar Islam dan Kristen. Pandangan ini juga ia kemukakan pada eksistensi historis agama Yahudi. Menurut Massignon tidaklah cukup kalau secara historis-teologis melihat titik permulaan hubungan antara Islam dan Kristen dalam

${ }^{8}$ Ibid. 167.

${ }^{9}$ Th. van den End, Ragi Carita 1, Sejarah Gereja di Indonesia 1500-1860, (Jakarta: Gunung Mulia, 1997), 175. 


\section{F A R A B I}

ISSN $1907-0993$

E ISSN $2442-8264$

Volume 17 Nomor 2 (Desember) 2020

pergaulan antar Nabi Muhammad dengan orang-orang Kristen dan Yahudi. Menurutnya, seyogyanya harus mundur lebih jauh ke belakang sampai pada tokoh Abraham, Ismael, dan Ishak yang terdapat titik pertemuan antara ketiga agama tersebut. Kesaksian Muhammad mengenai Allah adalah mengenai Allah Ibraham, dan kita hanya bisa mendapat pandangan yang jelas tentang Islam kalau kita mengakui adanya hubungan itu. ${ }^{10}$

Massignon memiliki wawasan yang khas, dimana agama-agama seperti Yahudi, Islam, dan Kristen merupakan ahli waris Abraham; agama Yahudi menonjolkan pengharapan, agama Kristen adalah kasih, dan agama Islam segi imannya. Agama Islam lahir menjadi kritik Ilahi terhadap agama Yahudi dan Kristen. Memang masih ada perbedaan pendapat antara orang-orang Kristen dan Islam mengenai ke-Allah-an Yesus Kristus. Tetapi, demikian Massignon, Muhammad sendiri berpendapat bahwa selisih paham ini dapat dibiarkan sampai kedatangan Yesus kembali. Lalu Yesus sendiri akan menyatakan pihak mana yang benar. Salah seorangg teolog modern J. Spencer Trimingham mengemukakan bahwa yang perlu adalah kesadaran dari kedua belah pihak, yang didalamnya terlibat baik emosi, kemauan maupun akal. Hanya dengan adanya dasar yang penuh simpati itu mungkin bisa menjelaskan bagaimana ajaran timbul dari pengalaman tentang Kristus. Artinya, orang boleh mengemukakan keyakinnya dengan memakai alasan-alasan intelektual, tetapi hanya setelah pengalaman yang berada dibelakanya diperkenalkan. ${ }^{11}$

\section{TEOLOG-TEOLOG YANG TIDAK MELIHAT ADANYA KONTINUITAS}

Seperti yang telah diuraikan di atas, bahwa ada beberapa teolog yang melihat adanya kontinuitas antara Kristen dan Islam, namun di sisi lain terdapat pandanganpandangan para teolog yang tidak melihat adanya kesinambungan antara kedua agama tersebut.

\section{Lahirnya agama Islam sebagai akibat penolakan yang sadar}

Para teolog yang mengartikan "Post-Kristen" sebagai "anti-Kristus" berusaha memberikan penjelasan dan argumen tentang sebab dan inti sifat anti-Kristus. A.Th. Van Leeuwen, pengarang buku yang terkenal "Christianity in World History" menulis

\footnotetext{
${ }^{10}$ Ibid. 191.

${ }^{11}$ J. Spencer Trimingham, The Christian Approach to Islam in the Sudan, (London-New York, 1948), 66.
} 


\section{F A R A B I}

ISSN $1907-0993$

E ISSN $2442-8264$

Volume 17 Nomor 2 (Desember) 2020

bahwa yang membuat Islam menjadi agama yang rasional karena adanya penyesuain dengan akal, dan terkadang penyesuai dengan nafsu-nafsu manusia seperti keinginan akan kemuliaan duniawi. Pandangan ini juga ditonjolkan oleh H. Kreamer dalam bukunya yang berjudul "De Islam als Godsdiensting en als Zendingsprobleem", merumuskan apa yang menurut Kreamer sebagai teka-teki dalam Islam:

"Islam adalah agama yang dangkal, namun benar-benar tahu memikat hati para pengikutnya. Islam tidak memiliki pemikiran yang orisinal, namun merupakan sistem keagamaan yang berbeda secara tajam dari agama-agama lain dan tahu memberi para pengikutnya rasa superioritas yang kuat terhadap agama-agama yang lain itu. Yang terutama merupakan teka-teki Islam ialah: bagaimana mungkin Tuhan membiarkan bertumbuh satu agama yang melenyapkan atau melumpuhkan Gereja Kristen di wilayah yang luas dan yang membuat hati penganutnya sekeras batu terhadap pengaruh Injil? ${ }^{12}$

Pandangan Kreamer di atas, adalah jawaban atas teka-teki dalam Islam dengan menafsirkan Islam sebagai teokrasi yang telah diduniawikan secara radikal. Kemudian Kreamer mengutip Pascal (1623-1662) yang dalam Pansèes-nya "Muhammad telah menempuh jalan keberhasilan secara manusiawi, Yesus Kristus memilih jalan kegagalan secara manusiawi. Kesimpulannya bahwa kita perlu mengatakan Muhammad berahasil maka Yesus Kristus mesti gagal". ${ }^{13}$

Demikianlah pandangan Kreamer terutama dalam dasawarsa terakhir. Ia cenderung menghakimi agama Islam dengan label-label yang kurang bersahabat. Pandangan Kreamer dinilai menyudutkan Islam sebagai agama rahmat. Namun harus diakui banyak para teolog yang tidak sepakat denga pandangannya. Para teolog yang tidak sepakat tersebut mengacu pada kenyataan bahwa dalam Islam modern, agama Islam dan hukum syari'ah tidak lagi dikaitkan secara mutlak, dan mereka lebih mementingkan kesalehan pribadi ketimbang kesalehan sosial yang tedapat dalam Islam.

\section{Allah Swt dan Bapa Yesus Kristus}

Dalam kasus ini, para teolog menyangkal bahwa Allah yang disembah oleh orang Islam adalah juga Allah orang Kristen. Dalam urainnya mengenai persoalan ini, H. Rosin dalam bukunya "The Lord of God", mengatakan bahwa "Allah bukanlah Allah Israel yang dinyatakan dalam diri Yesus Kritus". Maksudnya, nama YHWH dalam Perjanjian Lama tidak boleh diterjemahkan sebagai “Allah" tetapi harus disalin

\footnotetext{
${ }^{12}$ Th. van den End dan Christiaan de Jonge..., 124.

${ }^{13}$ Ibid. 124.
} 


\section{FA R A B I}

ISSN $1907-0993$

E ISSN $2442-8264$

Volume 17 Nomor 2 (Desember) 2020

sebagai "Tuhan". Istilah "Allah" boleh dipakai sebagai terjemahan "Elohim", sebagai sebutan umum "Dewa", atau sebagai terjemahan YHWH/Kyrios, di mana Alkitab memakai "Elohim" untuk menyebutkan Allah yang benar. Akan tetapi, nama pribadi "Allah" tidak boleh dipakai sebagai terjemahan nama pribadi "YHWH", karena, demikian Rosin mengatakan, "Nama Allah (dalam Islam) itu telah sama sekali kehilangan hubungannya dengan pusat yang lain dari pemberitaan Alkitab, yaitu NAMA itu". Artinya: dalam Alkitab NAMA itu dihubungkan dengan Pernyataan Allah dalam diri Tuhan Yesus Kristus.

Sebenarbya menurut Van den End Alkitab berbahasa Melayu terjemahan Leijdecker (abad ke-18) berdasarkan asas yang sama. Di situ, menurut Van den End, nama YHWH diterjemahkan dengan "Hu (a)", yang merupakan kata ganti orang dalam bahasa Arab (menyerupai "Yehova"): "Dia", "Dia itu”. Disamping itu terdapat "Allah", "Ilah" dan "Dewata". ${ }^{14}$ Asas itu ditinggalkan oleh Alkitab terjemahan Klinkert (1870/1879) dan Bode, tetapi diterima kembali dalam Terjemahan Baru LAI. ${ }^{15}$ Pendapat Rosin ini tidak berarti bahwa para teolog menyetujui Terjemahan Baru LAI yang seakan-akan Allah dalam al Quran dan Allah dalam Alkitab bukanlah Allah yang sama. Memang ada beberapa para teolog yang sependapat dengan Rosin misalnya Van Leeuwen berkata:

"Kesaksian bahwa "Tiada Allah selain Allah" memaklumkan pengetahuan umum tentang Allah dengan cara sangat eksklusif dan cemburu, seakan-akan hanya Allah yang menyatakan diri dalam Alkitab, artinya dalam satu pernyataan khusus. Bentuk Keyahudiannya dipertahankan, tetapi isinya tidak ada lagi. ${ }^{16}$

Selain itu Gairdner lebih bersikap hati-hati dalam persoalan ini. Ia mengatakah bahwa:

"Kalau hakikat satu hal terletak dalam sifat-sifatnya yang hakiki, maka Allah orang-orang Muslim bukanlah Allah Bapa orang-orang Kristen; lebih-lebih Isa dalam al Quran tidak sama dengan Yesus dari Injil. (...) Namun, yang dimaksudkan dalam al Quran ialah salinan yang tepat. (...) Mungkin cara orang Islam menggambarkan Allah kita di dalam Allah mereka, atau Kristus kita dalam Isa mereka, itu kurang sempurna, rusak secara tak terkatakan. Namun, itulah usaha mereka yang tulus dan sungguh-sungguh, dan orang Kristen tidak bisa tidak bertolak dari pengertian itu, lalu berusaha menunjukan kepada

\footnotetext{
${ }^{14}$ Th. van den End dan Christiaan de Jonge, op.cit. 165.

${ }^{15}$ Helimut Rosin, The Lord Of God, The Translation of the Divine Names and the, Missionary Calling of the Church, (Nederlandsch Bijbelgenootschap, 1956), 229-231.

${ }^{16}$ Ibid. 231.
} 


\section{FA R A B I}

ISSN $1907-0993$

E ISSN $2442-8264$

Volume 17 Nomor 2 (Desember) 2020

saudaranya satu demi satu ciri-ciri gambar yang asli yang patut dikasihi dan yang penuh kekayaan itu". ${ }^{17}$

Sebetulnya pandangan Gairdner di atas, dapat diikutkan dengan pandanganpandangan para teolog yang mengakui adanya kontinuitas antara Islam dan Kristen sebagai agama monoteistis. Dalam Agama Kristen, Allah (Tuhan) adalah Pribadi yang ada, yang tidak perlu diciptakan, karena Ia telah ada selamanya dan adalah penyebab dari segala sesuatu, termasuk dimensi waktu, yang tidak menjadi subjeknya. Keyakinan inti dalam agama Kristiani sama dengan agama Yahudi dan Islam adalah bahwa Allah itu Satu. Jemaat Kristiani berkeyakinan bahwa Allah mereka adalah Allah yang dipercaya oleh Ibrahim, Allah Musa dan bangsa Yahudi dan Allah umat Islam. Dengan kata lain, jemaat Kristiani melihat dirinya sebagai salah satu dari tiga komunitas umat beriman yang percaya pada Allah yang sama, yang berakar pada Ibrahim, yakni: komunitas Yahudi, Komunitas Kristiani, dan komunitas Islam. Orang-orang Kristiani memanggil Allah dengan sebutan "Bapa". Ini merupakan istilah yang berasal dari kalangan Yahudi, yang menyebut Allah sebagai bapak dan umat Yahudi adalah anakNya. ${ }^{18}$

Orang-orang Kristen mengakui Yesus sebagai Anak Allah yang diutus untuk menyelamatkan umat manusia dari kematian dan dosa. Yesus Kristus mengajarkan bahwa dia adalah Anak Allah. Kepercayaan bahwa Allah mempunyai anak, dibicarakan dalam 29 ayat dan terdapat dalam 19 surat dari semua periode. Paham Kristen bahwa 'Isa bukan hanya anak Tuhan, bahkan ia akhirnya Tuhan itu sendiri. ${ }^{19}$ Ajaran-ajarannya dapat diringkas, secara singkat sebagai cinta Tuhan dan cinta sesama. Yesus berkata bahwa ia datang untuk memenuhi hukum Allah daripada mengajarkannya. Orang-orang Kristen percaya pada pembenaran dengan iman bahwa melalui kepercayaan mereka kepada Yesus sebagai Anak Allah, dan dalam kematian dan kebangkitan-Nya, mereka dapat memiliki hubungan yang benar dengan Allah yang pengampunannya dilakukan sekali dan untuk selamanya melalui kematian Yesus Kristus. Keyakinan akan Yesus sebagai Anak Allah sperti terlihat dalam syahadat Nice sebagai berikut:

\footnotetext{
${ }^{17}$ Th. van den End dan Christiaan de Jonge..., 125.

${ }^{18}$ S.J., Thomas Michel, Pokok-Pokok Iman Kristiani: Sharing Iman Seorang Kristiani dalam Dialog Antar Agama, (Yogyakarta: Universitas Sanata Dharma, 2001), 40.

${ }^{19}$ G.C van Miftrik dan B.J. Boland, Dogmatika Masa Kini, (Jakarta: Gunung Mulia, 1995), 184.
} 


\section{FA R A B I}

ISSN $1907-0993$

E ISSN $2442-8264$

Volume 17 Nomor 2 (Desember) 2020

"Aku percaya akan Yesus Kristus, Anak Tunggal Allah, yang diperanakkan oleh Bapa lebih dahulu dari segala zaman. Allah keluar dari Allah...Allah yang benar keluar dari Allah yang benar, yang diperanakkan bukan dijadikan, sezat dengan Bapa... dia yang telah turun dari surga karena kita manusia dan karena keselamatan kita". ${ }^{20}$

Pandangan teolog yang tidak melihat adanya kontinuitas mengatakan bahwa Tuhan tidak tunduk pada ciptaan fisik, tetapi bersifat spiritual, yang berada di dimensi spiritual surga. Kuasa Tuhan atas ciptaan fisik adalah mutlak, sehingga Ia dapat memanipulasi materi, energi, ruang, dan waktu sesuka hati. Karena alasan ini, Tuhan dikatakan sangat berkuasa dan mampu menyelesaikan tugas yang mungkin Dia kehendaki untuk lakukan. Bersamaan dengan menjadi kuat, Tuhan juga mengetahui dan memiliki pengetahuan tentang semua hal yang mungkin diketahui, termasuk seluruh sejarah alam semesta masa lalu, sekarang, dan masa depan. Karena Allah Maha Kuasa (Mahakuasa) dan semua mengetahui (Mahatahu), Ia juga mampu hadir di semua tempat setiap saat (Mahakuasa).

Tuhan menurut Alkitab dalam surat Yohanes 4:16 adalah Maha Pengasih, "Tuhan itu kasih". ${ }^{21}$ Kasih Allah mendorong-Nya untuk menciptakan manusia menurut gambar-Nya, untuk membagikan kasih-Nya kepada kita. Kitab suci Kristen dalam surat Matius 22: 37-40 mengatakan bahwa kita dapat memenuhi seluruh hukum Allah dengan mengasihi Dia dan mengasihi sesama manusia. ${ }^{22}$ Tuhan itu benar-benar suci tanpa cacat moral atau karakter apa pun. Faktanya, Alkitab mengatakan bahwa Allah tidak mampu melakukan kejahatan apa pun, meskipun semuanya kuat. Tuhan tidak bisa diubah. Dengan kata lain, Dia tidak mengubah atribut atau karakter-Nya kapan pun. Terlepas dari kecenderungan manusia untuk mengubah definisi moralitasnya, karakter moral Allah tidak berkembang seiring dengan waktu, tetapi tetap konstan.

Dalam ajaran mainstream Protestan dan Katholik, Trinitas atau Tritunggal merupakan ajaran sentral dan karenanya Yesus adalah Tuhan Anak atau Anak Tuhan. Dogma Tritunggal mengimani ketuhanan Allah, Yesus Kristus dan Roh Kudus sekaligus. Dengan demikian, selain Allah itu sendiri, Yesus Kristus dan Roh Kudus

\footnotetext{
${ }^{20}$ Waryono Abdul Ghafur, "Beberapa Problem Teologis Antara Islam Dan Kristen," Esensia, Vol. XII, Nomor 1 Januari (2011): 102.

${ }^{21}$ Lembaga Al Kitab Indonesia, Al Kitab, (Jakarta: Lembaga Al Kitab Indonesia, Jakarta, 1984).

${ }^{22}$ Ibid.
} 


\section{F A R A B I}

ISSN $1907-0993$

E ISSN $2442-8264$

Volume 17 Nomor 2 (Desember) 2020

merupakan Tuhan atau Allah juga. Inilah ajaran ketuhanan yang sentral dalam agama kekristenan sebagaiamana tercantum dalam kredo iman rasuli, yaitu Tritunggal yang terdiri dari Allah Bapa, Allah Putra atau Anak, dan Roh Kudus. ketiga-tiganya adalah pribadi Allah dan ketiga-tiga pribadi tersebut adalah Allah. Kesemuanya Maha Kudus, Mahasempurna, Mahatahu, Mahakuasa dan kekal. Oleh karena itu ketiga-tiganya disembah dengan cara yang sama. Sekalipun terdiri dari tiga pribadi tetapi hanya satu Allah yang masing-masing memiliki suatu pengetahuan ilahi dan satu kehendak ilahi, sehingga disebut dengan Tritunggal yang Mahakudus. ${ }^{23}$

Perlu sekali untuk memperjelas "ke-Esa-an Allah" dalam konsep Kristiani, karena satu penjelasan atau teologi tentang sifat ketritunggalan Allah yang menolak keesaan-Nya tidak dipandang sebagai pernyataan iman Kristiani yang benar. Dalam satu perdebatan tentang boleh atau tidaknya oarng-orang Kristiani makan daging persembahan untuk berhala, St. Paulus mengatakan "Bahkan jika yang disebut "dewadewa" di langit dan di bumi betul-betul ada, bagi kami hanya ada satu Allah, yaitu Bapa, yang dari-Nya segala sesuatu berasal dan untuk-Nya kita hidup. Dengan kata lain, orang-orang Kristiani berbicara tentang Trinitas, itu selalu dalam rangka mengungkapkan ke-Esa-an Allah. ${ }^{24}$

Ajaran keTuhanan dalam kekristenan, baik Katholik maupun protestan pada dasarnya sama, yaitu trinitas atau tritunggal. Dalam menjelaskan ajaran ketuhanan menurut ajaran mainstream ini, penulis akan merujuk ajaran Kristen (Protestan). Kristosentrisme merupakan dasar dari ajaran-ajaran Kristen. Hal ini dapat dilihat dari kedudukan Yesus Kristus sebagai pusat segala-galanya dalam kehidupan seorang Kristiani dengan ajarannya yang terwujud dalam konsep inkarnasi, penebusan dan Trinitas. Selanjutnya, asas Protestan yang menonjol dapat dilihat dari dua hal: pertama, asas anti pemutlakan terhadap hal-hal yang nisbi, dan kedua, pembenaran iman (percaya). Dalam kepercayaan seorang Kristiani, manusia dapat bertemu dengan Allah dalam tiga tempat, yaitu: (1) dalam tatanan dan keagungan alam; (2) dalam pribadi Yesus Kristus yang hidup dalam sejarah, dan (3) dalam hati nurani manusia. Segi-segi kehidupan tersebut masing-masing ada pada Tuhan Bapak, Tuhan Anak dan Roh

\footnotetext{
${ }^{23}$ Ismail, Roni, dkk (editor.), Agama-agama Dunia, (Yogyakarta: Jurusan Perbandingan Agama, 2012), 492, 574.

${ }^{24}$ S.J., Thomas Michel..., 57.
} 


\section{F A R A B I}

ISSN $1907-0993$

E ISSN $2442-8264$

Volume 17 Nomor 2 (Desember) 2020

Kudus, dan dapat dipelajari dari isi dan makna yang tercantum dalam 12 pasal "Pengakuan Iman Rasuli.",25

Tuhan adalah Wujud tertinggi yang ada, sempurna dalam kekuatan, cinta, dan karakter. Karena Tuhan ingin membagikan kasih-Nya kepada orang lain, Dia menciptakan para malaikat dan manusia - makhluk spiritual yang dapat berhubungan dengan-Nya. Karena Tuhan adalah cinta, Dia ingin kita mencintai-Nya dan mengasihi orang lain (Matius 22: 37-40). ${ }^{26}$ Allah datang ke bumi dalam wujud manusia sebagai Yesus dari Nazaret untuk mengajar kita tentang diri-Nya dan untuk memberikan pengorbanan tertinggi bagi dosa-dosa kita, sehingga mereka yang percaya dapat memiliki persekutuan dengan-Nya. Alkitab menganjurkan semua orang untuk beralih dari keegoisan mereka untuk menjadi pecinta Allah, untuk memenuhi hukum kasih Allah yang sempurna.

\section{TAUHID: TITIK TEMU ISLAM-KRISTEN}

Keberadaan akan banyaknya agama dan klaim bahwa semua agama menuntun kepada Allah jelas-jelas membingungkan banyak orang yang dengan sungguh-sungguh mencari kebenaran tentang Allah, yang berakhir dengan keputusasaan dari beberapa orang apakah mereka dapat mendapatkan kebenaran yang mutlak mengenai topik itu. Atau mereka akhirnya memeluk klaim universalis bahwa semua agama menuntun kepada Allah.

Pada bagian ini penulis akan membahas kesatuan agama-agama yang mengejutkan di antara kitab-kibat Yudaeo-Kristen di satu sisi, dan al Quran serta Hadits di sisi lain. Bagi kaum Muslimin al Quran merupakan wahyu Tuhan yang diberikan kepada Nabi Muhammad pad antara tahun 610 hingga 632 Masehi. Umat Islam percaya bahwa al Quran mengandung kata-kata yang benar-benar berasal dari Allah swt. kata perkata yang disampaikan kepada Nabi Muhammad melalui perantaraan Malaikat Jibril. Dengan demikian al Quran merupakan otoritas tertinggi dalam Islam.

Sebagai titik awal guna menjelajahi kesatuan agama-agama yang berkitabkan Yudaeo-Kristen dan teks-teks agama Islam, maka ada 4 (empat) isu pokok yang dipandang sebagai dasar kesatuan agama-agama tersebut: 1) kesatuan dalam aspek

\footnotetext{
${ }^{25}$ Banawiratma, JB. SJ (ed.), Kristologi dan Allah Tritunggal, (Yogyakarta: Kanisius, 1986), 546.

${ }^{26}$ Lembaga Al Kitab Indonesia.
} 


\section{F A R A B I}

ISSN $1907-0993$

E ISSN $2442-8264$

Volume 17 Nomor 2 (Desember) 2020

ketuhanan dan pesan-Nya (wahyu); 2) kesatuan kenabian; 3) tidak ada paksaan dalam beragama; dan 4) pengakuan terhadap eksistensi agama lain. Semua yang demikian disebut normatif karena sudah merupakan ketetapan Tuhan.

Dengan latar belakang kesamaan esensial ini, tidaklah mengherankan bila Islam, Yahudi dan Kristen kerap digolongkan sebagai tiga agama Ibrahim. Walaupun sistem klasifikasi berdasarkan kesamaan warisan yang berasal dari Ibrahim. Bagi beberapa pihak, bisa jadi tampak kelewat partikularistik, lepas dari sistem kalisifikasi macam apa yang digunakan, Yahudi, Kristen dan Islam secara konsisten selalu terkelompok bersama. Sama sekali bukan satu kebetulan kalau tiga agama tersebut berada dalam satu kelompok secara konsisten dalam berbagai konseptual. Walaupun tiap-tiap agama memiliki dogma dan doktrin unik berkenan dengan dirinya sendiri, masing-masing memiliki sebuah inti yang secara esensial sama dengan inti kedua agama lainnya. Tiaptiap agama mengklaim warisan historis yang sama dalam tradisi kenabian, kendati mungkin berbeda-beda dalam menafsirkan peristiwa-peristiwa historis dan kenabian yang spesifik. Tiap-tiap agama memiliki inti ajaran agama dan etika yang sama, kendati dalam sejumlah aspek berbeda-beda terkait dengan doktrin dan dogma khusus.

Frithjof Schuon berusaha untuk menganalisis hubungan antar agama-agama. Dasar pemikirannya adalah, bahwa setiap hal memiliki persamaan sekaligus perbedaan dengan hal-hal lainnya. Persamaan, paling tidak dalam adanya hal-hal itu sendiri. Perbedaan, karena kalau tidak, pasti tidak akan ada keragaman yang dapat diperbandingkan. Demikian pula halnya dengan agama-agama. Bila tidak ada persamaan pada agama-agama, kita tidak akan menyebutnya dengan nama yang sama "agama" ${ }^{27}$ Bila tidak ada perbedaan diantaranya, kita pun tidak akan menyebutnya dengan kata majemuk "agama-agama", dan karena itu kata benda tunggal akan lebih cepat untuk itu. Dimanakah akan ditarik garis antara kesatuan dan kemajemukan diantara keduanya? mengajukan teori tentang "Perbedaan antara hakekat dan perwujudan esoteris lawan eksoteris". Kajian ini didasarkan kepada ajaran yang bersipat metafisik, bukan bersipat filosofis. Schuon menarik garis pemisah antara yang eksoteris dan esoteris.

${ }^{27}$ Frithjof Schuon, Mencari Titik Temu Agama-Agama, terj. Safroedin Bahar, (Jakarta: Pustaka Firdaus 1987). ix 


\section{FA R A B I}

ISSN $1907-0993$

E ISSN $2442-8264$

Volume 17 Nomor 2 (Desember) 2020

Kenyataannya memakai analogi sebuah pohon, masing-masing agama mengklaim sebagai satu-satunya perpanjangan vertikal batang pohon berisi sekumpulan wahyu Ilahi utama, yang paling sejati, sementara dua agama lainnya dipandang sebagai cabang-cabang yang telah menyimpang dari vertikalitas sejati batang yang orisinal. ${ }^{28}$ Jika argumentasi ini terus terbangun maka kita bisa melihat nasib masa depan hubungan agama-agama tidak akan baik. Sebab masing-masing mempertahankan kebenaran agamanya dan pada akhirnya klaim kebenaran hanya akan merusak hubungan antar umat beragama seperti yang terjadi selama ini. Konflik agama di beberapa daerah adalah akibat dari klaim-klaim itu.

\section{PENUTUP}

Pendekatan esoteris itu bisa memperoleh pemahaman tentang "kesatuan" yang absolut, kategoris dan utuh. Secara antropologis, kesatuan ini menutup kemungkinan bagi munculnya perbedaan akhir antara yang manusiawi dan ilahi. Sedangkan secara epistimologis, kesatuan yang sama akan meniadakan kemungkinan bagi munculnya perbedaan akhir antara yang mengetahui dan diketahui. Inilah yang memungkinkan kita memahami bahwa versi Schuon tentang perbendaan antara hakekat dan perwujudan agama sangat penting artinya. Menurut pandangannya, kelemahan versi-versi lain mengenai perbedaan ini karena versi-versi tadi terlalu cepat menyatakan adanya kesatuan, padahal sesungguhnya kesatuan tersebut tidak terjangkau karena bercorak eksoteris sebagaimana terlihat pada garis bawah, nampak berbagai agama itu terpecah belah. Namun, perbedaan tingkat ini merupakan hal yang mendasar. Tanpa perbedaan tersebut akan terjadi kebingungan yang tidak dapat dielakkan.

Satu hal yang perlu ditegaskan dalam tulisan ini adalah, satu-satunya hal yang sampai sekarang dapat dikatakan tentang hubungan antara agama Islam dan Kristen ialah "agama Islam bersifat Post-Kristen. Inilah yang membedakan Islam dengan agama-agama lainnya, seperti Buddah, Hindu, Tao, Konghuchu, dan lain-lainya. PostKristen" itu tidak berarti bahwa agama Islam lahir sesudah munculnya agama Kristen, tetapi bahwa agama Islam menurut asal dan hakikatnya ditentukan oleh pertemuan dengan agama Kristen (dan Yahudi). Tetapi dengan cara ini pun timbulnya agama Islam tetap merupakan teka-teki bagi orang-orang Kristen.

\footnotetext{
${ }^{28}$ Jerald F. Dirks, Abrahamic Faith: Titik Temu dan Titik Seteru antara Islam, Kristen dan Yahudi. (Jakarta: Serambi, 2004). 30-31.
} 


\section{F A R A B I}

ISSN $1907-0993$

E ISSN $2442-8264$

Volume 17 Nomor 2 (Desember) 2020

\section{DAFTAR PUSTAKA}

Armstrong, Karen, Perang Suci (penterjemah) Hikmat Darmawan. Jakarta: Serambi. 2004.

Banawiratma, JB. SJ (ed.), Kristologi dan Allah Tritunggal. Yogyakarta: Kanisius. 1986.

Berkhof, H. dan I.H. Enklaaar, Sejarah Gereja. Jakarta: BPK. 1994.

Departemen Agama RI, Al-Qur'an al-Karim dan Terjemahnya. Solo: Qomary. 2006.

End, Dr. Th. van den dan Christiaan de Jonge, Sejarah Perjumpaan Gereja dan Islam, STT Jakarta. 1997.

End, Dr. Th. van den, Ragi Carita 1, Sejarah Gereja di Indonesia 1500-1860.PT BPK. Jakarta: Gunung Mulia. 1997.

G.C van Miftrik dan B.J. Boland, Dogmatika Masa Kini, Jakarta: Gunung Mulia. 1995.

Harun. M. Yahya. Perang Salib dan Pengaruh Islaam di Eropa. Yogyakarta: Bina Usaha. 1987.

Ismail, Roni, dkk (editor.), Agama-agama Dunia. Yogyakarta: Jurusan Perbandingan Agama. 2012.

Kilgour, Rev. R, D.D. Alkitab di Tanah Hindia Belanda. Jakarta: Lembaga Alkitab Indonesia. t.tahun.

Lembaga Al Kitab Indonesia, Al Kitab, Jakarta: Lembaga Al Kitab Indonesia. 1984

McGavran, Grace W, Alkitab di Seluruh Dunia: 48 Kisah Nyata. Lembaga Literatur Baptis, Bandung. 1993.

Michel, S.J., Thomas, Pokok-Pokok Iman Kristiani: Sharing Iman Seorang Kristiani dalam Dialog Antar Agama, Yogyakarta: Universitas Sanata Dharma. 2001.

Moffet. S.H, A Histrory of Christianity in Asia, I Beginnings to 1500. San Fransisco: Harper. 1992.

Mohammad Mustafa al-Azamai, 'I'Jaz dalam Pemeliharaan Sunnah Nabi Muhammad $S A W$ ' dalam Iwan Kusuma Hamdan dkk (penterjemah dan Editor), Mukjizat Al-qur'an dan As-Sunnah tentang IPTEK I. Jakarta: Gema Insani Press. 1997.

Rosin, Helimut, The Lord Of God, The Translation of the Divine Names and the. Missionary Calling of the Church. (Nederlandsch Bijbelgenootschap. 1956.

Schumann, O, Pemikiran Keagamaan dalam Tantangan. Jakarta: Gramedia. 1993.

Trimingham, J. Spencer, The Christian Approach to Islam in the Sudan. London-New York. 1948.

Waryono, "Beberapa Problem Teologis Antara Islam Dan Kristen," Esensia, Vol. XII, Nomor 1 Januari (2011): 97-118.

Waryono, Abdul Ghafur, Kristologi Islam. Yogyakarta: Pustaka Pelajar. 2006. 


\section{F A R A B I}

ISSN $1907-0993$

E ISSN $2442-8264$

Volume 17 Nomor 2 (Desember) 2020

Watt, W. Montgomery and P. Cachia. A History of Islamic Spain, Edinburgh: University Press. 1992.

Schuon, Frithjof. Mencari Titik Temu Agama-Agama, terj. Safroedin Bahar, (Jakarta: Pustaka Firdaus 1987.

Dirks, Jerald F. Abrahamic Faith: Titik Temu dan Titik Seteru antara Islam, Kristen dan Yahudi. Jakarta: Serambi. 2004 